\title{
The many faces of solitary fibrous tumor; diversity of histological features, differential diagnosis and role of molecular studies and surrogate markers in avoiding misdiagnosis and predicting the behavior
}

\author{
Muhammad Usman Tariq ${ }^{1}$, Nasir Ud Din ${ }^{1}$, Jamshid Abdul-Ghafar ${ }^{2^{*}}$ (ID and Yong-Koo Park ${ }^{3}$
}

\begin{abstract}
Background: Solitary Fibrous Tumor (SFT) is a distinct soft tissue neoplasm associated with NAB2-STAT6 gene fusion. It can involve a number of anatomic sites and exhibits a wide spectrum of histological features.

Main body: Apart from diversity in morphological features seen even in conventional SFT, two histologic variants (fat-forming and giant cell-rich) are also recognized. In addition, a malignant form and dedifferentiation are well recognized. Owing to diverse histological features and involvement of diverse anatomic locations, SFT can mimic other soft tissue neoplasms of different lineages including schwannoma, spindle cell lipoma, dermatofibrosarcoma protuberans, liposarcoma, gastrointestinal stromal tumor (GIST), malignant peripheral nerve sheath tumor (MPNST), and synovial sarcoma. SFT is classified as an intermediate (rarely metastasizing) tumor according to World Health Organization Classification of Tumors of Soft tissue and Bone, 5th edition. The management and prognosis of SFT differs from its malignant mimics and correct diagnosis is therefore important. Although SFT expresses a distinct immunohistochemical (IHC) profile, the classic histomorphological and IHC profile is not seen in all cases and diagnosis can be challenging. NAB2-STAT6 gene fusion has recently emerged as a sensitive and specific molecular marker and its IHC surrogate marker signal transducer and activator of transcription 6 (STAT6) has also shown significant sensitivity and specificity. However, few recent studies have reported STAT6 expression in other soft tissue neoplasms.
\end{abstract}

Conclusion: This review will focus on describing the diversity of histological features of SFT, differential diagnoses and discussing the features helpful in distinguishing SFT from its histological mimics.

Keywords: Solitary fibrous tumor, Hemangiopericytoma, STAT-6, NAB2-STAT6, CD34, Staghorn, fusion transcript, Immunohistochemistry

\footnotetext{
* Correspondence: jamshid.jalal@fmic.org.af

${ }^{2}$ Department of Pathology and Clinical Laboratory, French Medical Institute for Mothers and Children (FMIC), Kabul, Afghanistan

Full list of author information is available at the end of the article
}

(c) The Author(s). 2021 Open Access This article is licensed under a Creative Commons Attribution 4.0 International License, which permits use, sharing, adaptation, distribution and reproduction in any medium or format, as long as you give appropriate credit to the original author(s) and the source, provide a link to the Creative Commons licence, and indicate if changes were made. The images or other third party material in this article are included in the article's Creative Commons licence, unless indicated otherwise in a credit line to the material. If material is not included in the article's Creative Commons licence and your intended use is not permitted by statutory regulation or exceeds the permitted use, you will need to obtain permission directly from the copyright holder. To view a copy of this licence, visit http://creativecommons.org/licenses/by/4.0/ The Creative Commons Public Domain Dedication waiver (http://creativecommons.org/publicdomain/zero/1.0/) applies to the data made available in this article, unless otherwise stated in a credit line to the data. 


\section{Background}

The morphological features of solitary fibrous tumor (SFT) were originally described in 1931 by Klemperer and Rabin in a series of 5 cases of pleural neoplasms [1]. Similar tumors were named "solitary (localized) mesothelioma of pleura" by Stout and Murray in 1942 [2]. These tumors were renamed "solitary fibrous tumor" by Stout and Hamidi in 1951 [3]. The term "Hemangiopericytoma" (HPC) was used for the first time by Stout and Murray in 1942 while describing a series of 9 cases [4]. The diagnostic criteria for HPC were refined and features for assessment of malignancy were established by Enzinger and Smith in a large study of 106 cases [5]. Until 1990, SFT was reported only in pleura and lung [6]. The first series of extra-thoracic SFT was published in 1991 [7]. Even before the identification of a unifying molecular signature, owing to their clinicopathological similarities, SFT and HPC were considered to represent two ends of histomorphological spectrum of a single tumor entity $[8,9]$. The molecular hallmark of these tumors is the recurrent fusion of NAB2 and STAT6 genes located at chromosomal region 12q13 [10-12]. These tumors were merged together into a single entity in 4th edition of World Health Organization (WHO) Classification of Tumors of Soft Tissue and Bone [13]. Current WHO Classification of Soft Tissue and Bone Tumors has classified SFT as a fibroblastic neoplasm with intermediate (rarely metastasizing) behavior [14]. However, in the current WHO Classification of Tumors of Central Nervous System, extrameningeal SFT and HPC are described as a single group but different histologic grades are assigned to these tumors while retaining the names [15].

\section{Main text}

\section{Clinical features}

SFTs can occur in patients over a wide age range with peak incidence in 5th and 6th decades of life. These tumors are rare in children and adolescents $[14,16]$. SFTs have been reported at almost every anatomic site. Pleura is the most common site and accounting for approximately $30 \%$ cases. Other frequently involved sites include meninges (27\%), abdominal cavity (20\%), trunk (10\%), extremities (8\%) and head \& neck (5\%) [17]. Pleural SFTs present at somewhat older age (mean = 60.2 years) compared to meningeal (mean $=50.6$ years) and extra-pleural SFTs (mean $=50.3$ years) [18]. No known risk factors for development of SFTs are currently known [16]. SFTs are usually asymptomatic, slow growing tumors which are often discovered as an incidental finding on imaging [19]. These tumors sometimes produce symptoms related to pressure effects on adjacent tissues/organs [14].

Tumor size can range from 1 to $40 \mathrm{~cm}$ with median size of $5-8 \mathrm{~cm}[14,19]$. SFTs of head and neck are generally smaller in size than the more slowly growing tumors of abdominal cavity may reach larger size over a longer time period before causing significant symptoms [14, 20]. SFTs usually involve deep soft tissues but few tumors may occur in superficial locations [21, 22]. Some SFTs present with "Doege-Potter Syndrome", a paraneoplastic hypoglycemic syndrome resulting from excessive production of insulinlike growth factor II (IGF2) [23, 24].

\section{Gross features}

Grossly, conventional SFTs are often well-circumscribed and partially encapsulated with a multinodular, whitish, firm cut surface (Fig. 1a). Myxoid change and hemorrhage may be seen in some cases. Malignant and locally aggressive tumors may show irregular infiltrative borders and necrotic areas (Fig. 1b) [14, 17].

\section{Histological features}

Histologically, SFTs are variably cellular tumors composed of ovoid to spindled cells exhibiting patternless growth or a storiform pattern against a variably collagenous background stroma containing thin-walled large branching, "staghorn"-shaped (HPC-like) blood vessels (Fig. 2a\&b). Medium sized blood vessels with perivascular fibrosis are also commonly seen (Fig. 2c) [17, 25]. The background stroma may show focal or diffuse myxoid change (Fig. 2d) [25-27]. Classic fibrous SFTs are paucicellular tumors composed of spindle shaped cells arranged in short wavy fascicles or haphazardly present against prominent fibrous stroma with cracking artifact and abundant keloid-type collagen (Fig. 3a\&b). These cells have uniform, elongated or fusiform nuclei and scant cytoplasm. Cellular SFTs are more cellular and composed of spindle shaped and rounded cells with round to oval nuclei having condensed chromatin. Perivascular fibrosis is frequently present. Gaping blood vessels are more frequently seen at the periphery of tumors (Fig. 3c\&d). Markedly cellular tumors (still known as HPCs in meninges) are composed of sheets of more primitive-appearing rounded cells (Fig. 4a\&b).

The vascular channels in SFT lack a connective tissue layer and the endothelial cells merge with surrounding tumor cells. Fibrotic background and perivascular fibrosis are not seen [20]. HPC-like vasculature can be seen in other mesenchymal tumors including various soft tissue sarcomas $[5,10]$. This gave rise to a debate whether HPC was a distinct tumor entity or simply a nonspecific histomorphological pattern seen in various tumor types [28-30].

In comparison to pleural and extra-pleural tumors, meningeal tumors are more frequently cellular and show HPC type morphology [18]. SFTs generally show low mitotic activity and lack significant nuclear pleomorphism and/or necrosis [14]. 

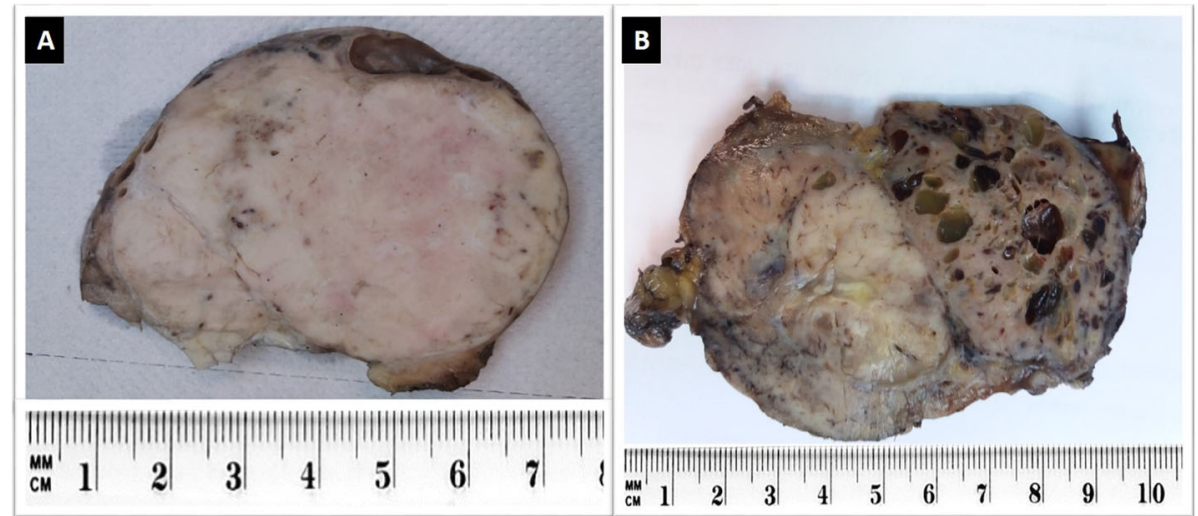

Fig. 1 Gross appearance of SFT: a. Benign SFT appearing as a well-circumscribed, white and firm tumor. b. Malignant SFT of retroperitoneum exhibiting ill-defined borders, variegated cut surface and cystic degeneration

Some variants of SFTs show prominence of certain unusual morphological features. These include fatforming, giant cell-rich and dedifferentiated variants [17]. The fat-forming variant of SFT or lipomatous HPC shows abundance of mature adipocytes in stroma (Fig. 4c). This variant usually involves deep soft tissues but has been reported in orbit, neck, parotid gland, mediastinum, stomach, retroperitoneum, paratesticular soft tissue and thigh [31-34]. The giant-cell variant of SFT shows many multinucleated stromal giant cells usually arranged around pseudovascular spaces (Fig. 4d). This variant was previously known as giant cell angiofibroma and most of these cases involved periorbital soft tissue. However, it has also been reported in several extraorbital locations such as head and neck, retroperitoneum, back, vulva, hip, and inguinal region [35-37].

Like other soft tissue tumors, dedifferentiation is also observed in SFT. The dedifferentiated variant is extremely rare and shows abrupt transition to a low or high-grade sarcoma with adjacent conventional SFT. The dedifferentiated component is mostly in the form of spindle cell sarcoma not otherwise specified or
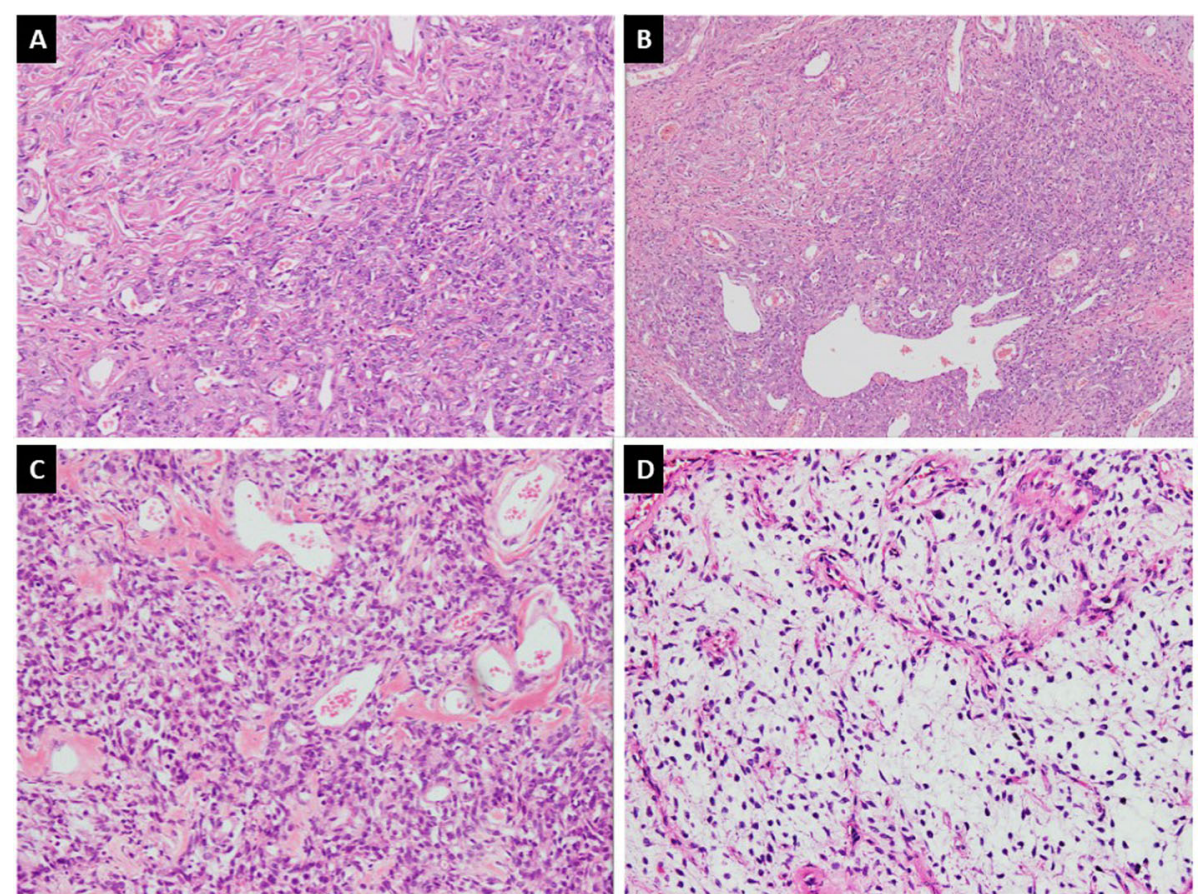

Fig. 2 a. SFT exhibiting hypo and hypercellular areas of spindle cells against collagenous background stroma along with, b. HPC-like vessels, c. stromal and perivascular fibrosis and, $\mathbf{d}$. myxoid change in stroma 

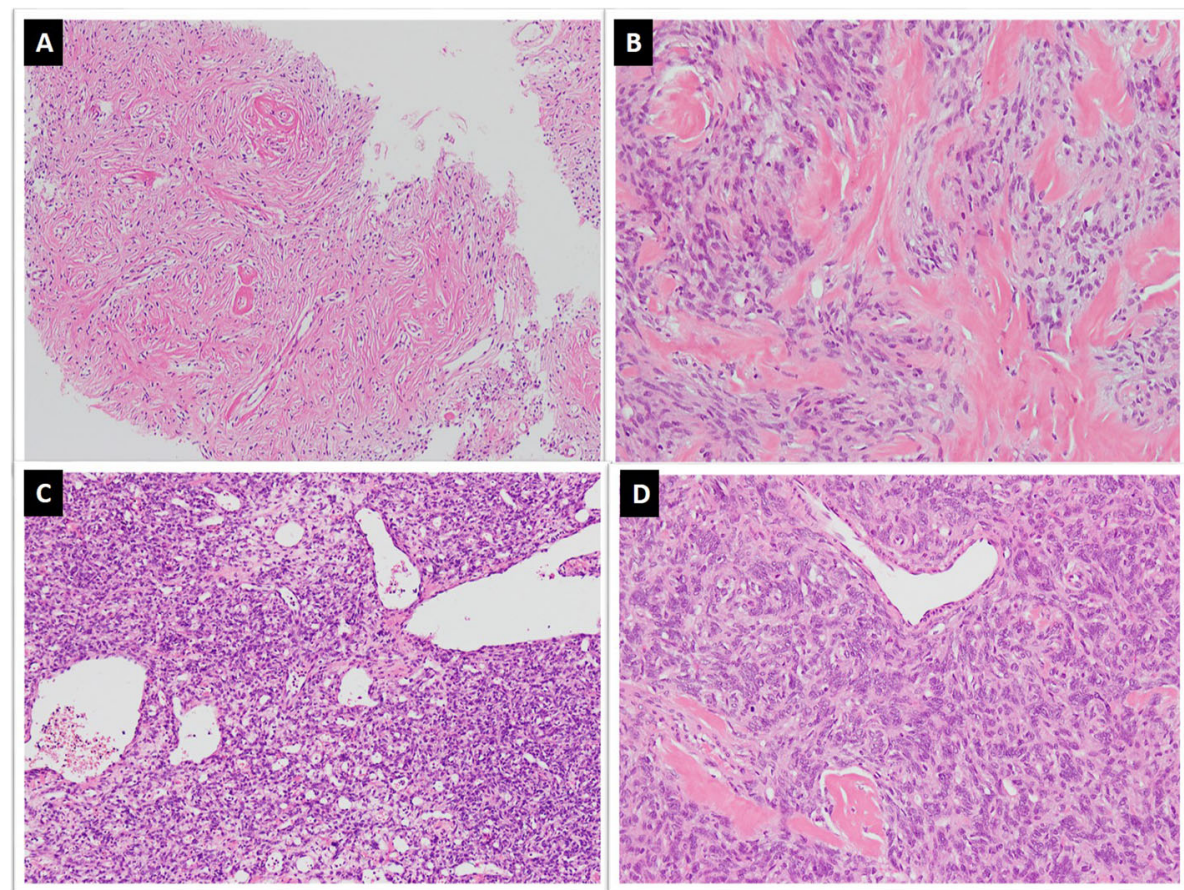

Fig. 3 a. Classic SFT exhibiting cracking artifact and, b. abundant keloid-type collagen, $\mathbf{c} \& \mathbf{d}$. Cellular SFT exhibiting increased cellularity, gaping blood vessels and more darkly stained nuclei

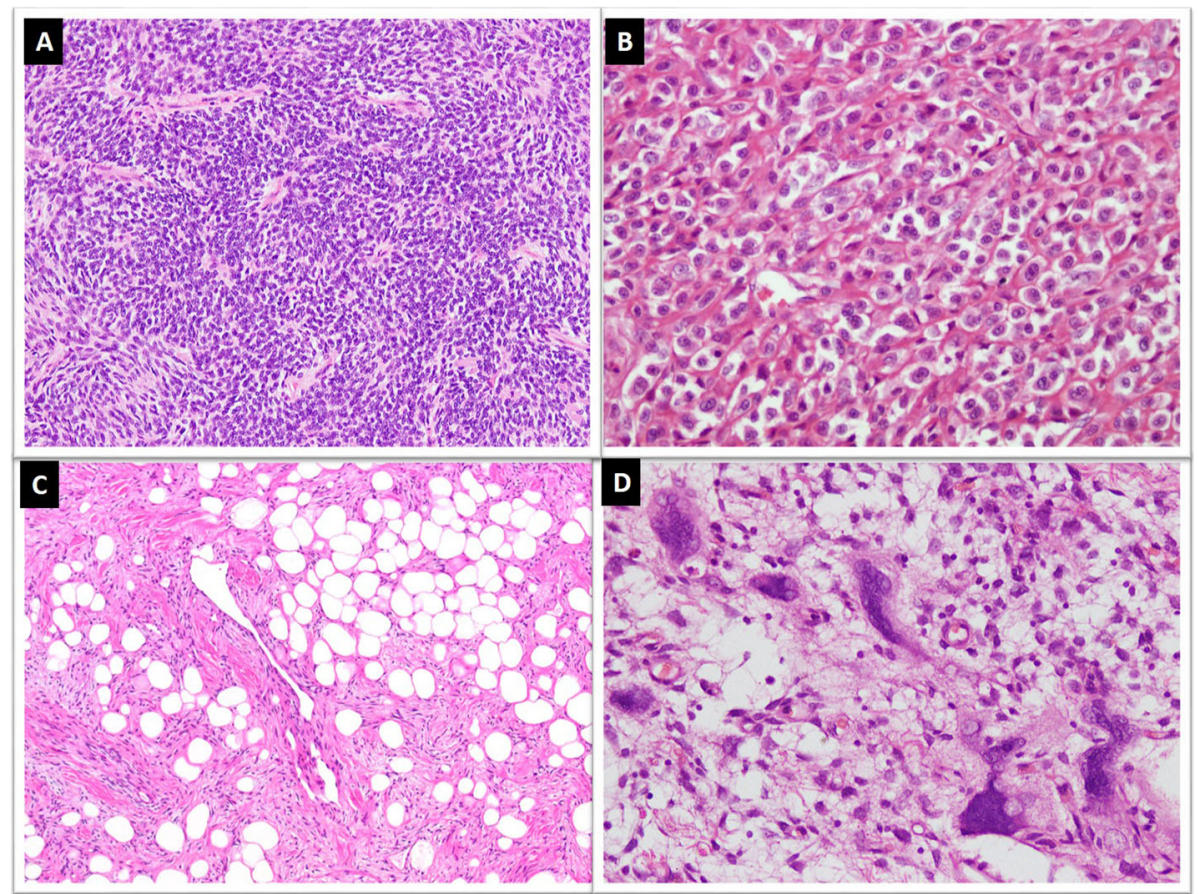

Fig. 4 a. Markedly cellular tumor showing sheets of small sized cells with hyperchromasia, $\mathbf{b}$. Tumor cells exhibiting round cell morphology, c. Lipomatous SFT composed of mature adipocyte intermixed with tumor cells, $\mathbf{d}$. Giant cell SFT exhibiting multinucleated giant cells focally lining pseudovascular spaces 
undifferentiated pleomorphic sarcoma (Fig. 5a\&b) and can rarely show osteosarcomatous or rhabdomyosarcomatous differentiation [38-43]. Dedifferentiation may be seen in primary or recurrent tumors. It can be associated with loss of expression of immunohistochemical markers and newer molecular alterations. Occasional squamous and neuroendocrine differentiation has also been reported in SFTs [40].

\section{Features suggestive of malignant behavior}

Different clinical and histomorphological features have been described which are suggestive of malignancy. These features include older age, larger tumor size, increased cellularity, increased mitotic activity $(\geq 4 / 10 \mathrm{HPFs}$ or $>2$ mitoses $/ 2 \mathrm{~mm}^{2}$ ), nuclear pleomorphism, tumor necrosis and infiltrative borders [5, 6, 14, 17, 20, 44-47]. Tumors lacking malignant histological features in primary resection specimens may acquire malignant features at time of recurrence and metastases [47].

In extra-pleural and extra-meningeal tumors, Pasquali et al. found hypercellularity, increased mitotic rate and nuclear pleomorphism to be associated with recurrence and hypercellularity and pleomorphism to be associated with reduced overall survival [48]. Demicco et al. reported patient age, tumor size and mitotic rate to be associated with time to metastasis and tumor related death, and necrosis to be a predictor of metastasis [49]. Tumor size is usually considered to be a negative prognostic factor but SFTs can grow to a large size without behaving aggressively [14, 48]. Kim et al. assessed the utility of different risk assessment systems in SFTs from different sites and found mitotic rate $(>4 / 10 \mathrm{HPF})$ to be the only independent prognostic factor [18]. Yamada et al. identified dedifferentiation as a major adverse prognostic factor and hypoglycemia, cerebromeningeal and intra-abdominal locations to be associated with poor prognosis [43].
TP53 immunohistochemical (IHC) expression has also been found to be associated with recurrence and/or metastasis [50]. In one study, TERT promoter mutations were found to be predictors of metastasis-free survival in intermediate risk category of SFT [51]. One of the latest risk stratification models by Demicco et al. is based on assessment of patient's age, mitoses $/ \mathrm{mm}^{2}$, tumor size and percentage of tumor necrosis. It stratifies SFTs into low, intermediate and high-risk categories and is more accurate in predicting the prognosis [52].

\section{Immunohistochemical features of SFT}

A combination of CD34, CD99 and BCL-2 has been widely used to diagnose SFT. These IHC markers are sensitive and usually show diffuse and strong expression in approximately 90\% cases (Fig. 6a-c). However, these markers have limited usefulness due to their expression in other neoplasms closely mimicking SFT histologically $[21,53]$. CD34 expression has been observed in 81-95\% SFTs but its expression is lost especially in malignant and dedifferentiated tumors [54-57]. BCL-2 is a more sensitive marker (>90\% sensitivity) while CD99 is less sensitive ( $75 \%$ sensitivity). However, specificity of both these markers is quite low $[21,53,54,58,59]$.

STAT6 IHC stain has emerged as a useful surrogate marker of NAB2-STAT6 gene fusion with excellent sensitivity and specificity and is also expressed in malignant cases (Fig. 6d) [55, 56, 60]. In a recent study, diffuse and strong nuclear expression for STAT6 IHC marker was observed in all 52 cases but gene fusion was detected by reverse transcription polymerase chain reaction in 48 (92\%) cases (RT-PCR) [20].

STAT6 IHC marker can also be expressed in some other soft tissue neoplasms such as well differentiated liposarcoma (WDL) or dedifferentiated liposarcoma (DDL), desmoid fibromatosis, unclassifiable sarcoma, neurofibroma, myxoid liposarcoma, undifferentiated pleomorphic sarcoma, low grade fibromyxoid sarcoma,

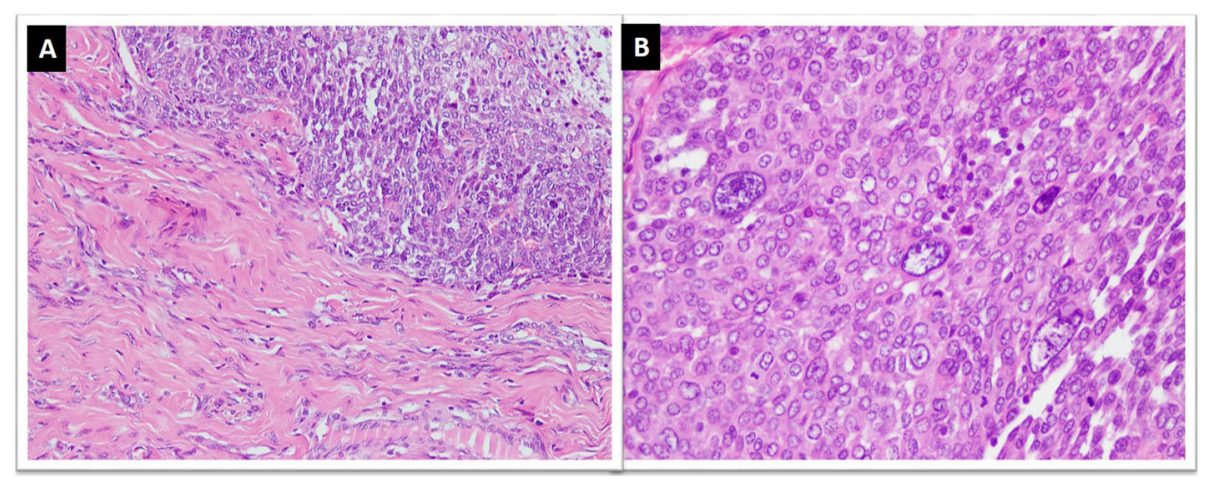

Fig. 5 Dedifferentiated SFT; a. Abrupt transition of conventional SFT areas with high grade sarcomatous areas with, b. marked nuclear pleomorphism and increased mitoses 


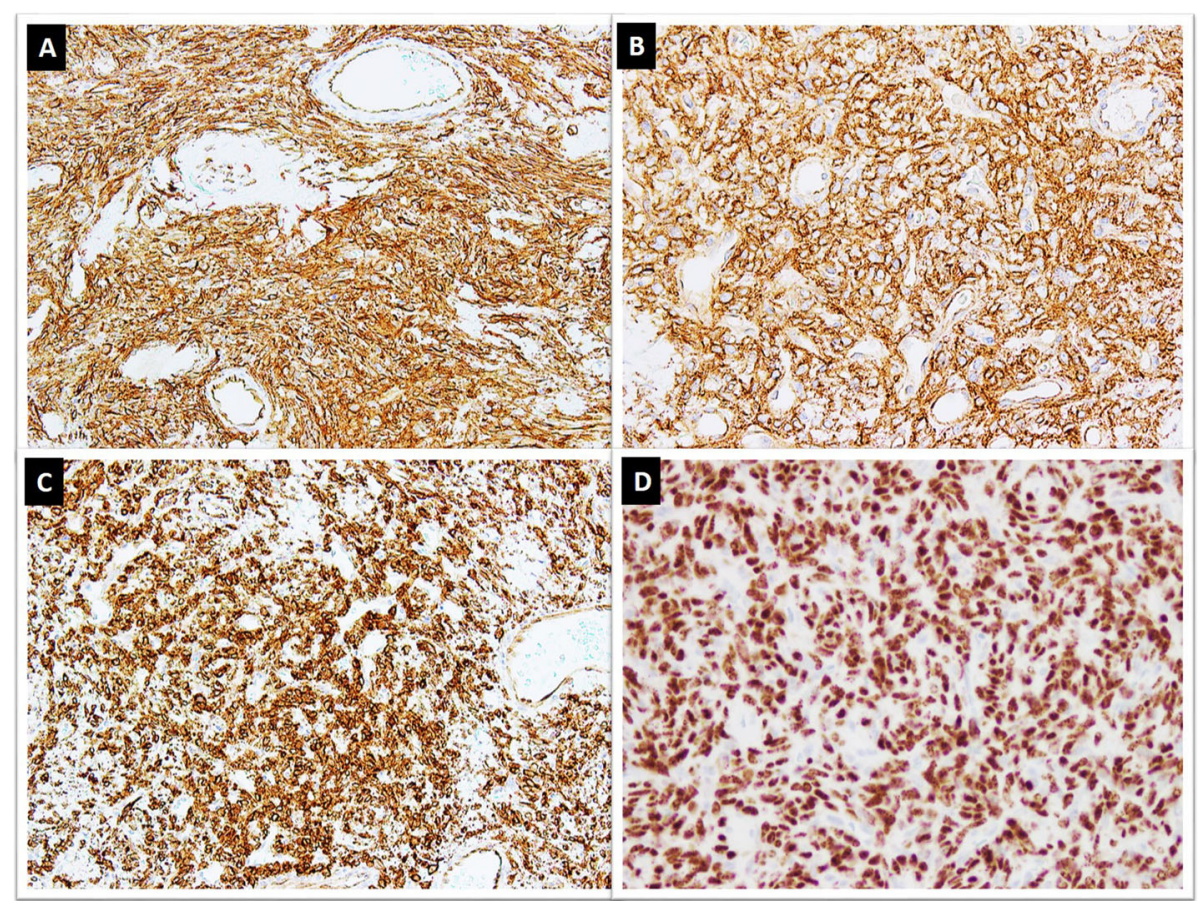

Fig. 6 Tumor cells showing positive staining for, a. CD34, b. CD99, c. BCL2 and, d. nuclear staining for STAT6 IHC stains

synovial sarcoma (SS) and ovarian fibroma [17, 61, 62]. Doyle et al. observed positive STAT6 expression in 4 out of 35 (11\%) cases of DDL [61]. In a large study, Demicco et al. assessed STAT6 expression in 1781 non-SFT mesenchymal tumors and observed strong nuclear expression in $4 \%$ cases. Tumors which demonstrated positive expression included unclassifiable sarcoma $(8 / 65\{12 \%\})$, WDL and DDL (49/409\{12\%\}), desmoid tumor/fibromatosis $(14 / 184\{8 \%\})$, neurofibroma $(3 / 60\{5 \%\})$, clear cell sarcoma $(1 / 19\{5 \%\})$, myxoid liposarcoma $(2 / 108\{2 \%\})$ and undifferentiated pleomorphic sarcoma $(2 / 173\{1 \%\})$. Ouladan et al. evaluated STAT6 expression in 374 nonSFT mesenchymal tumors and positive nuclear staining was observed in only 4 (1\%) cases including 2 cases of WDL, 1 case of DDL and 1 case of SS [63]. STAT6 expression was also found in a small subset of nonneoplastic tissue including scar tissue and adipose tissue [62]. In a series of prostatic SFT and smooth muscle tumors of uncertain malignant potential (STUMP), the sensitivity and specificity of STAT6 for SFT was 91 and $75 \%$ respectively [64]. The expression of STAT6 in SFT is exclusively nuclear but other tumors may show both nuclear and cytoplasmic staining [62].

Gene expression profiling studies have also identified overexpression of GRIA2 gene and aberrant expression of GRIA2 protein in SFT [12]. This protein is usually expressed in central nervous system tissue and epithelia of some organs but can also be expressed in soft tissue tumors such as SFT and dermatofibrosarcoma protuberans
(DFSP) [54]. In one study, overall frequency of GRIA2 IHC expression in SFT was $80 \%$. The frequency was $86 \%$ in malignant cases and $100 \%$ in dedifferentiated cases [17].

Another study found aldehyde dehydrogenase 1 (ALDH1) to be a useful marker for SFT. It was expressed in $76 \%$ cases, and along with STAT6 expression, was found be a useful marker for distinguishing SFT from its soft tissue mimics [63]. ALDH1 was also found to be helpful in differentiating meningeal SFT from meningioma and SS [57].

Some cases of pleural and abdominal SFT may show multifocal expression of cytokeratins [65]. Few cases of SFT may also show focal expression for epithelial membrane antigen (EMA), alpha smooth muscle actin (ASMA), beta catenin, glial fibrillary acidic protein (GFAP) and neuron-specific enolase (NSE). Conversely, expression of h-caldesmon, desmin, CD31 and S100 is almost always negative [65]. TP53 IHC expression is observed in malignant cases [50].

\section{Differential diagnosis}

Owing to diversity of histological patterns exhibited by SFT, Machado et al. termed SFT "the great simulator" of soft tissue tumors [25]. SFTs often pose diagnostic challenge and integration of clinical, histomorphological, immunohistochemical and molecular features is necessary for establishing correct diagnosis [17]. In extra-pleural locations, the pathologist must rule out tumors which are more common in those particular sites [17]. 
Comparison of clinical, histomorphological, immunohistochemical and molecular features of SFT with some of the tumors important in differential diagnosis is summarized in Table 1.

Monophasic and poorly differentiated SSs mimic SFTs owing to sheet-like growth pattern, spindle to ovoid cell morphology, HPC-like vasculature in some cases and CD99 and BCL-2 expression [14]. Occasional cases may also show positivity for STAT6 [61, 62]. However, CD34 expression is almost always absent in SS. Some cases of SFT may also show weak expression of TLE1. However, strong and diffuse nuclear expression of TLE1 favors the diagnosis of SS. Molecular studies for translocation $t(X ; 18)$ are recommended for confirmation of diagnosis [14, 66].

Malignant peripheral nerve sheath tumor (MPNST) is composed of cellular sheets of spindle cells which may alternate with hypocellular areas. Tumor cells may show HPC-like vasculature and accentuation around blood vessels. Some cases of low grade MPNST may also demonstrate positive expression for CD34. Majority of MPNSTs show typical "nerve sheath morphology" at least focally. Loss of H3K27me3, STAT6 negativity and expression of SOX-10, S100 or GFAP favors MPNST [21, 66].

Primary intrapulmonary SFTs are uncommon tumors which need to be differentiated from a number of mesenchymal, epithelial and mixed tumors. Intrapulmonary SFTs especially need to be distinguished from sarcomatoid carcinoma. Squamous cell carcinoma, carcinoid tumor and malignant mesothelioma (originating from pleura) may also show spindle cell morphology and mimic SFT [24]. Multifocal expression for cytokeratins, observed in some pleural and abdominal SFTs, can be misleading as two important differential diagnoses in these locations (sarcomatoid carcinoma and mesothelioma) also show similar staining pattern [65]. Other mesenchymal intrapulmonary tumors such as inflammatory myofibroblastic tumor (IMT), leiomyosarcoma, leiomyoma, and adenofibroma should also be considered in the differential diagnosis (DD). Positive expression for CD34 and STAT6 IHC stains helps in establishing the diagnosis of SFT [24, 61, 62].

Fat-forming or lipomatous SFT can resemble benign lipomatous tumors such as spindle cell lipoma (SCL) or malignant lipomatous tumors such as WDL or DDL. Spindle cell lipoma exhibits bland spindle cells, ropy collagen bundles and mature adipose tissue and expresses CD34 immunostain. All these features are seen to a variable degree in lipomatous SFT. However, STAT6 expression is not observed in SCL. RB1 gene loss by fluorescence in situ hybridization (FISH) is also observed in SCL.

DDLs exhibit a wide variety of histological features which resemble low- and high-grade sarcomas. In retroperitoneal location especially, DDL can resemble malignant fat-forming SFT. The situation is further complicated by STAT6 nuclear expression in DDL. Mouse double minute 2 (MDM2) gene amplification and diffuse nuclear IHC expression in DDL is extremely helpful in this situation because of $100 \%$ specificity and $97.2 \%$ sensitivity. CDK4 and p16 are also useful IHC markers for the diagnosis of WDL and DDL [31-34, 61, 66, 67, 69, 71-73].

Cellular schwannomas can also resemble SFT as these are composed of fascicles of bland spindle shape cells against a collagenous background and frequently exhibit thick-walled and hyalinized blood vessels. Some cases may show CD34 expression. Presence of thick fibrous capsule, foamy macrophages, lymphoid infiltrate, wavy nuclei with tapered ends and S100 expression favors the diagnosis of schwannoma [66].

Angiofibroma of soft tissue is a circumscribed tumor composed of bland spindle cells against variably collagenous to myxoid background stroma containing a rich network of thin-walled blood vessels. Tumor cells are variably positive for CD34, EMA and Desmin. STAT6 expression is typically negative. The molecular signature of this tumor is translocation $\mathrm{t}(5 ; 8)$ ( $\mathrm{p} 15 ; \mathrm{q} 13)$ resulting in AHRR-NCOA2 fusion gene [68].

Myofibromas are biphasic tumors occurring in young age which can resemble SFT due to pericytic growth pattern and presence of HPC-like vasculature. These tumors variably express CD34 and ASMA. Presence of myoid nodules at the periphery of the tumor is unique to myofibroma and provides a useful diagnostic clue [70].

Myofibroblastomas are circumscribed tumors composed of intersecting fascicles of bland spindle shaped myofibroblastic cells with intervening collagen bundles and occasional mature adipocytes. Tumor cells demonstrate positivity for CD34, Desmin and ASMA IHC stains. These tumors also show RB1 gene loss by FISH which is not observed in SFT [71].

Cellular angiofibroma is another well circumscribed, multilobulated tumor composed of spindle cells against a collagenous and edematous background stroma containing small to medium sized thick walled and hyalinized blood vessels. Some cases also show mature adipocytes and collagen bundles. Variable expression for CD34, ASMA and Desmin may be seen. RB1 gene loss is also observed [71].

Deep fibrous histiocytoma also exhibits intersecting fascicles or storiform pattern of bland spindle cells. Stromal hyalinization and HPC-like vessels are also seen. Tumor cells may show positive expression for CD34 and ASMA but STAT6 is negative [21].

In superficial locations, two soft tissue tumors with CD34 expression need to be distinguished from SFT [22]. These tumors are DFSP and superficial CD34 positive fibroblastic tumor (SCD34PFD). DFSP is a dermal based tumor usually composed of fairly uniform spindle cells with elongated nuclei arranged in storiform pattern 
Table 1 Differential Diagnosis of Solitary Fibrous Tumor

\begin{tabular}{|c|c|c|c|c|c|c|}
\hline & Age (years) & $\begin{array}{l}\mathrm{M}: \mathrm{F} \\
\text { ratio }\end{array}$ & Sites & Histological features & IHC & $\begin{array}{l}\text { Key genetic } \\
\text { alterations }\end{array}$ \\
\hline $\begin{array}{l}\text { Solitary Fibrous } \\
\text { Tumor }[10,21]\end{array}$ & 40 to 70 & Equal & $\begin{array}{l}\text { Pleura } \\
\text { Meninges; CNS \& spinal } \\
\text { cord } \\
\text { Deep soft tissues of } \\
\text { extremities } \\
\text { Abdominal cavity, the } \\
\text { pelvis, or the } \\
\text { retroperitoneum } \\
\text { Head and neck } \\
\text { Trunk }\end{array}$ & $\begin{array}{l}\text { Patternless spindled to ovoid cells } \\
\text { within a variably collagenous } \\
\text { stroma, admixed with branching } \\
\text { and hyalinized staghorn-shaped } \\
\text { (hemangiopericytomatous) blood } \\
\text { vessels. }\end{array}$ & $\begin{array}{l}\text { CD34+, } \\
\text { STAT6+ }\end{array}$ & $\begin{array}{l}\text { fusion of the } \\
\text { NAB2 and STAT6 } \\
\text { genes }\end{array}$ \\
\hline $\begin{array}{l}\text { Synovial Sarcoma, } \\
\text { Monophasic }[14,21]\end{array}$ & $\begin{array}{l}\text { Adolescents } \\
\& \text { young } \\
\text { adults }(2 / \\
\text { 3rds }<50 \\
\text { years })\end{array}$ & $1.2: 1$ & $\begin{array}{l}\text { Most often deep soft } \\
\text { tissues of extremities or } \\
\text { limb girdles, distal } \\
\text { extremities (fingers, hand } \\
\text { foot), Head and \& Neck }\end{array}$ & $\begin{array}{l}\text { Fascicles \& sheets of uniform } \\
\text { spindle cells. May have a } \\
\text { herringbone pattern. HPC like } \\
\text { branching vessels are common. } \\
\text { Often contain stromal hyalinized or } \\
\text { wiry collagen bundles }\end{array}$ & $\begin{array}{l}\text { SYT +, TLE1+, } \\
\text { EMA+, CK+, } \\
\text { STAT6- }\end{array}$ & SYT-SSX1/2 \\
\hline $\begin{array}{l}\text { Malignant Peripheral } \\
\text { Nerve Sheath Tumor } \\
{[21,66]}\end{array}$ & $\begin{array}{l}20-50 \\
\text { (median 35) }\end{array}$ & Equal & $\begin{array}{l}\text { Trunk and extremities, } \\
\text { followed by the head and } \\
\text { neck area }\end{array}$ & $\begin{array}{l}\text { Hypercellular \& hypocellular } \\
\text { fascicles of spindle-shaped cells } \\
\text { (marbleized pattern), perivascular } \\
\text { accentuation, HPC-like vascular } \\
\text { pattern, increase mitoses, geo- } \\
\text { graphic necrosis, heterologous dif- } \\
\text { ferentiation in 15\% of cases }\end{array}$ & $\begin{array}{l}\text { S100+ }(< \\
50 \%) \\
\text { SOX10+ } \\
70 \%) \\
\text { GFAP+ }(20- \\
\text { 30\%) } \\
\text { H3K27me3 } \\
\text { Loss }\end{array}$ & $\begin{array}{l}\text { NF1, CDKN2A/ } \\
\text { CDKN2B, and } \\
\text { PRC2 core } \\
\text { components (EED } \\
\text { or SUZ12) } \\
\text { mutations }\end{array}$ \\
\hline $\begin{array}{l}\text { Dedifferentiated } \\
\text { Liposarcoma [67] }\end{array}$ & $\begin{array}{l}27-81 \\
\text { (mean age } \\
52 \text { ) }\end{array}$ & Equal & $\begin{array}{l}\text { Retroperitoneum, } \\
\text { spermatic cord and (more } \\
\text { rarely) mediastinum, head } \\
\text { and neck, and trunk. }\end{array}$ & $\begin{array}{l}\text { Fascicles or sheets of atypical } \\
\text { spindle cells along with lipogenic } \\
\text { component with atypia }\end{array}$ & $\begin{array}{l}\text { MDM2+, } \\
\text { CDK4+, p16+, } \\
\text { CD34+/-, } \\
\text { STAT6-/+ }\end{array}$ & $\begin{array}{l}\text { MDM2 \& CDK4 } \\
\text { amplification }\end{array}$ \\
\hline $\begin{array}{l}\text { Sarcomatoid } \\
\text { Mesothelioma [65] }\end{array}$ & $\begin{array}{l}\text { 41-94 } \\
\text { (median 70) }\end{array}$ & $22: 1$ & Pleura, Peritoneum & $\begin{array}{l}\text { Fascicles or haphazardly } \\
\text { distributed atypical spindle cells } \\
\text { with increase mitoses. Densely } \\
\text { collagenized stroma with } \\
\text { hypocellular atypical spindle cells } \\
\text { in desmoplastic mesothelioma }\end{array}$ & $\begin{array}{l}\text { CK+, EMA+, } \\
\text { D2-40+, } \\
\text { Calretinin+, } \\
\text { WT1 + }\end{array}$ & BAP mutation \\
\hline $\begin{array}{l}\text { Soft Tissue } \\
\text { Angiofibroma [68] }\end{array}$ & $\begin{array}{l}\text { Middle age, } \\
\text { peak in 60th } \\
\text { decade }\end{array}$ & $0.75: 1$ & $\begin{array}{l}\text { Usually subcutis of } \\
\text { extremities, particularly } \\
\text { involving around large } \\
\text { joints like knee }\end{array}$ & $\begin{array}{l}\text { Variably myxoid to collagenous } \\
\text { stroma, branching capillary } \\
\text { network \& uniform bland spindle } \\
\text { cells with ovoid or tapering nuclei. } \\
\text { Perivascular collagenization }\end{array}$ & $\begin{array}{l}\text { EMA }-/+ \\
\text { CD34 }-/+\end{array}$ & AHRR-NCOA2 \\
\hline $\begin{array}{l}\text { Spindle Cell Lipoma } \\
\text { [69] }\end{array}$ & $40-60$ & $10: 1$ & $\begin{array}{l}\text { Subcutis of posterior neck, } \\
\text { upper back \& shoulders } \\
\text { Face, scalp, orbit, oral } \\
\text { cavity \& extremities rarely } \\
\text { involved }\end{array}$ & $\begin{array}{l}\text { Short fascicles of bland spindle } \\
\text { cells with short stubby nuclei, } \\
\text { variable number of adipocytes, } \\
\text { and ropy collagen bundles. } \\
\text { Fibromyxoid stroma, mast cells }\end{array}$ & $\begin{array}{l}\text { CD34+, ASMA } \\
-, \text { Desmin -, } \\
\text { S100- }\end{array}$ & RB1 deletion \\
\hline Myofibroma [70] & $\begin{array}{l}\text { First decade } \\
(<2 \text { years }) \\
\text { Adults }\end{array}$ & $\begin{array}{l}2: 1 \\
\text { Equal }\end{array}$ & $\begin{array}{l}\text { Skin \& subcutis of } \\
\text { extremities, head \& neck \& } \\
\text { trunk. } \\
\text { Infantile cases involve } \\
\text { liver, heart, GIT, brain \& } \\
\text { bone }\end{array}$ & $\begin{array}{l}\text { Distinctive biphasic pattern with } \\
\text { nodules comprising of immature } \\
\text { spindle cells in center with HPC- } \\
\text { like vasculature and whorls of } \\
\text { myoid cells at periphery with a } \\
\text { basophilic pseudochondroid } \\
\text { appearance }\end{array}$ & $\begin{array}{l}\text { ASMA+/-, } \\
\text { CD34 }-/+ \\
\text { Desmin }+\end{array}$ & Nil \\
\hline $\begin{array}{l}\text { Myofibroblastoma } \\
\text { [71] }\end{array}$ & $\begin{array}{l}\text { 50-60 } \\
\text { (median 54) }\end{array}$ & $2: 1$ & $\begin{array}{l}\text { Most cases involve } \\
\text { Inguinal/groin area (vulva/ } \\
\text { vagina, perineum, and } \\
\text { scrotum) }\end{array}$ & $\begin{array}{l}\text { Short fascicles of spindle cells with } \\
\text { short stubby nuclei, interspersed } \\
\text { broad collagen bands \& variable } \\
\text { admixture of mature adipocytes }\end{array}$ & $\begin{array}{l}\text { CD34+, } \\
\text { Desmin + } \\
\text { ASMA+/- }\end{array}$ & RB1 deletion \\
\hline $\begin{array}{l}\text { Cellular } \\
\text { Angiofibroma [71] }\end{array}$ & $\begin{array}{l}5 \text { th decade } \\
\text { in women, } \\
7 \text { th decade } \\
\text { in men }\end{array}$ & Equal & $\begin{array}{l}\text { Vulvovaginal/ } \\
\text { inguinoscrotal \& } \\
\text { paratesticular region }\end{array}$ & $\begin{array}{l}\text { Randomly distributed short, } \\
\text { intersecting fascicles of spindle } \\
\text { cells containing stubby nuclei. } \\
\text { Scattered medium sized hyalinized } \\
\text { vessels. Wispy stromal collagen }\end{array}$ & $\begin{array}{l}\text { ER \& PR }+ \\
(50 \%), C D 34+/ \\
-, \text { Desmin } \\
-/+, \text { ASMA } \\
-/+\end{array}$ & RB1 deletion \\
\hline $\begin{array}{l}\text { Deep Fibrous } \\
\text { Histiocytoma [21] }\end{array}$ & $\begin{array}{l}\text { 6-84 } \\
\text { (median 37) }\end{array}$ & $\begin{array}{l}\text { Slightly } \\
\text { more in }\end{array}$ & $\begin{array}{l}\text { Extremities followed by } \\
\text { head and neck region }\end{array}$ & $\begin{array}{l}\text { Uniformly cellular storiform to } \\
\text { short fascicular pattern of plump }\end{array}$ & $\begin{array}{l}\text { CD34 + (40\%), } \\
\text { ASMA f+/- }\end{array}$ & $\mathrm{Nil}$ \\
\hline
\end{tabular}


Table 1 Differential Diagnosis of Solitary Fibrous Tumor (Continued)

\begin{tabular}{|c|c|c|c|c|c|c|}
\hline & Age (years) & $\begin{array}{l}\text { M:F } \\
\text { ratio }\end{array}$ & Sites & Histological features & IHC & $\begin{array}{l}\text { Key genetic } \\
\text { alterations }\end{array}$ \\
\hline & & male & & $\begin{array}{l}\text { spindle cells. HPC-like branching } \\
\text { vessels, stromal hyalinization }\end{array}$ & STAT6 - & \\
\hline $\begin{array}{l}\text { Dermatofibrosarcoma } \\
\text { Protuberans [75] }\end{array}$ & $20-40$ & $\begin{array}{l}\text { Slight } \\
\text { male }\end{array}$ & $\begin{array}{l}\text { Trunk, proximal } \\
\text { extremities, head and } \\
\text { neck region, genital area, } \\
\text { the breast, and at acral } \\
\text { sites }\end{array}$ & $\begin{array}{l}\text { Dermal uniform spindle cells } \\
\text { arranged in storiform, whorls \& } \\
\text { short fascicles. Infiltration of results } \\
\text { in "honeycomb" appearance. }\end{array}$ & $\begin{array}{l}\text { CD34+, } \\
\text { ASAMA +/-, } \\
\text { STAT6 - }\end{array}$ & COLIA-PDGFB \\
\hline $\begin{array}{l}\text { Cellular Schwannoma } \\
\text { [66] }\end{array}$ & $40-60$ & Equal & $\begin{array}{l}\text { Paravertebral, } \\
\text { retroperitoneum, pelvis \& } \\
\text { mediastinum }\end{array}$ & $\begin{array}{l}\text { Predominantly or exclusively } \\
\text { composed of Antoni A areas with } \\
\text { interlacing fascicles of spindle cells } \\
\text { having tapered nuclei. Hyalinized } \\
\text { vessels are focally seen }\end{array}$ & $\begin{array}{l}\text { S100+, } \\
\text { SOX10+, } \\
\text { STAT6- }\end{array}$ & NF2 mutations \\
\hline
\end{tabular}

and infiltrating into the subcutaneous adipose tissue. SCD34PFD is also a dermal based tumor comprising of sheets and fascicles of spindle to epithelioid cells. Tumor cells have moderate cytoplasm and may show moderate to marked atypia [74]. In comparison to these tumors, SFTs have relatively more defined borders and heterogeneous cellularity. Molecular studies on DFSP typically show translocation $t(17 ; 22)$ and/or supernumerary ring chromosome $\mathrm{r}(17 ; 22)$ [75].

In abdominal (and less commonly extra-abdominal) locations, one important lesion which should be considered in the $\mathrm{DD}$ is low grade gastrointestinal stromal tumor (GIST) which often shows spindle to ovoid cells arranged in fascicles or randomly distributed. In addition, CD34 expression is shared by GISTs and SFTs. However, majority of GISTs are positive for CD117 and DOG1 while STAT6 is always negative [14].

In meninges, meningothelial meningioma can be easily distinguished from SFT by epithelioid cell morphology, whorling, syncytial pattern and psammomatous calcifications [76]. Fibrous meningioma can resemble SFT due to spindle cell morphology and vague fascicular pattern. Atypical and anaplastic meningioma can mimic malignant SFT due to presence of patternless/sheet-like growth, necrosis, frequent mitoses, nucleolar prominence, nuclear pleomorphism and small cell change. Meningiomas usually express positivity for EMA and progesterone receptor (PR). This expression is either completely or partially lost in atypical and anaplastic cases. However, all types of meningioma are negative for CD34 and STAT6 IHC stains [76]. Therefore, a panel of these IHC stains should be applied in meningeal tumors when SFT is considered in the DD [77].

In hypercellular SFTs, tumor cells usually acquire round cell morphology and mimic small round cell sarcomas such as Ewing sarcoma (ES), rhabdomyosarcoma and mesenchymal chondrosarcoma (MC) [25]. Due to high incidence of rhabdomyosarcoma in young patients with head and neck tumors, it should be kept in the differential diagnosis. Presence of cambium layer and rhabdomyoblastic differentiation along with absence of HPC-like vasculature are useful clues in favor of rhabdomyosarcoma. In addition, myogenic markers like MyoD1, myogenin and desmin are highly sensitive and specific markers for rhabdomyosarcoma and are usually not expressed in SFT $[21,78,79]$.

The round cell population of mesenchymal chondrosarcoma also shows background HPC-like vasculature which may be indistinguishable from SFT on morphology. This raises a diagnostic challenge if chondroid component is not sampled in small biopsy specimens. Both ES and MC like SFT express CD99. Positivity for NKX2.2 which is a recently introduced sensitive and specific IHC marker for ES and expression of CD34 and STAT6 by SFTs help in reaching the correct diagnosis $[21,25]$.

Myxoid change in SFT is well reported and a number of other soft tissue tumors with myxoid features must be excluded. These tumors include low grade myxofibrosarcoma, low grade fibromyxoid sarcoma and myxoid liposarcoma $[25-27,55,60,80,81]$. Some of these tumors may express CD34 and occasional cases with STAT6 expression have also been reported. Careful examination of tumor for cases showing conventional SFT morphology along with diffuse and strong nuclear STAT6 expression leads to accurate diagnosis [61, 62].

Soft tissue tumors with epithelioid morphology such as epithelioid sarcoma and epithelioid angiosarcoma sometimes need to be considered in the DD [25]. SFT with giant cells is a rare occurrence and the DD of this morphological form include soft tissue sarcomas with giant cell component and nodular fasciitis [25, 82].

Prostatic stromal tumors of uncertain malignant potential (STUMP) and prostatic stromal sarcoma (PSS) can pose diagnostic problems for pathologists. STUMP exhibits haphazard fascicles of spindle cells which do not exhibit significant nuclear atypia or mitoses. However, PSS exhibits solid growth of spindle to epithelioid cells with nuclear atypia, increased mitoses and necrosis. However, these demonstrate a more regular pattern 
histologically, lack HPC-like vasculature and collagen deposition [55, 83]. Some of these tumors may express positivity for CD34 and some of the prostatic SFTs may also express PR [83]. However, STUMP and PSS lack nuclear expression for STAT6. Combined specificity of STAT6 and ALDH1 is $100 \%$ for SFTs of this region [55].

\section{Molecular alterations in SFT}

A number of studies have identified recurrent fusion of two genes in majority of SFTs by next generation sequencing (NGS) and RT-PCR techniques. This gene fusion is considered to be an initial event in the tumorigenesis of SFT $[12,20]$. These two genes, NGFI-A binding protein 2 (NAB2) and STAT6 are located very close to each other on chromosome 12 [10-12]. Therefore, their fusion is difficult to detect by FISH technique [12]. In a study conducted by Barthelme et al., diffuse and strong nuclear IHC expression for STAT6 was observed in $100 \%$ cases while gene fusion was detected in 92\% cases by RT-PCR. Lack of gene fusion detection was not related to technical issues in RNA isolation from formalin fixed tissue [20].

NAB2 is a transcriptional repressor while STAT6 is a transcription factor. Both proteins play important roles in regulation of inflammation, fibroblastic activation, collagen formation and vessel formation $[84,85]$. These proteins affect early growth response 1 (EGR1) transcription factor which is an important regulator of fibrosis and wound healing in opposing manner [85-87]. NAB2 gene possesses 7 exons while STAT6 gene possesses 23 exons. As a result, a number of fusion variants are generated with variable frequencies [10-12].

In a study of 52 pleural and extra-pleural tumors, 12 fusion variants were identified by multiplex RT-PCR in 48 (92\%) cases. Three fusion variants were more frequent and accounted for $75 \%$ of all fusion variants. Fusion variants were grouped according to their potential functional effects among the predicted chimeric proteins. These fusion categories significantly correlated with patient age, tumor size, mitotic activity, anatomic site, histomorphological classification and clinical follow up. Majority of the tumors harboring NAB2ex4STAT6ex2/3 gene fusion variant involved thoracic cavity and showed classic fibrous SFT morphology. When compared with tumors having other fusion variants, these tumors had higher tumor age, larger tumor size, lower mitotic activity and lower recurrence rate. Majority of the tumor harboring NAB2ex6-STAT6ex16 and NAB2ex6-STAT6ex17 fusion variants were deep seated and involved extra-thoracic sites. These tumors occurred in significantly younger age group, were smaller in size, showed higher mitotic activity, cellular SFT or typical HPC type morphology and higher recurrence rate [20].
Robinson et al. also found that majority of the tumors with gene fusion variant NAB2ex6-STAT6ex16/17 were extra-thoracic in location while two out of three tumors with NAB2ex4-STAT6ex $2 / 3$ gene fusion variant were seen in pleuropulmonary location [10]. In a study by Chmielecki et al., majority of the tumors with NAB2ex4STAT6ex2 gene fusion variant involved lung or pleura. NAB2ex6-STAT6ex16/17 gene fusion variant was not detected [11]. Mohajeri et al. observed that the majority of tumors with NAB2ex6-STAT6ex16/17 gene fusion variants were located in extra-thoracic regions while half of the tumors with NAB2ex4-STAT6ex2 gene fusion variant involved pleuropulmonary region [12]. Yamada et al. and Park et al. did not find any direct association of gene fusion variants with malignancy. However, they observed that the association between gene fusion variants and tumor location could indirectly affect the biological behavior of SFT [43, 50].

TERT promoter mutations were found to be associated with malignant SFTs in two studies [50, 51]. A comprehensive genetic analysis in that study also revealed down regulation of target genes of EGR1 [12]. Overexpression of genes encoding stem cell markers such as ALDH1 has also been demonstrated. ALDH1 has been related to poor prognosis in breast carcinoma. In addition, a number of growth factors and kinases are overexpressed in SFTs. These include PDGF $\alpha$, PDGF $\beta$, PDGFR- $\alpha$, PDGFR- $\beta$, IGF1R, EGFR, VEGF, IGF2, c-Met, c-kit, c-erbB2, PTEN, phosphorylated (p) AKT, pS6, p4EBPEGFR, ERBB2, FGFR1, and JAK2 [88]. Overexpression of these markers leads to activation of Akt/ mTOR pathway and appears to be associated with tumor necrosis [89]. Targeting Akt/mTOR pathway and IGF signaling pathway might prove beneficial for irresectable tumors [89]. PDGFR- $\alpha$ is more frequently expressed in malignant SFTs compared to more localized tumors [90]. A number of studies have also reported complete loss or partial deletion of chromosomes 1,6,9,13,15,17, $18, \mathrm{X}$ and gain of chromosomes 5,8,13,21 [91-94]. In a recent study, TP53 mutations were identified in $41 \%$ malignant SFTs [50]. Dedifferentiated SFTs also characteristically show TP53 mutations [25, 41-43, 95].

\section{Follow up and prognosis}

In one study, malignant SFTs were related with higher rate of local recurrence and distant metastasis [96]. In another study, tumors with malignant histological features demonstrated indolent behavior while tumors lacking malignant histological features behaved aggressively $[44,47]$. Extrathoracic site is an independent predictor of poor prognosis. Tumors located in meninges, pelvis, retroperitoneum and mediastinum are associated with greater risk of recurrence [46]. Despite surgical excision with clear margins, local recurrence and distant 
metastasis can occur in some cases [13]. In one study, local recurrence was observed in 13 (39.3\%) out of 39 cases [20]. Distant metastasis is a predictor of poor prognosis and $75 \%$ patients with metastasis die of their disease [97]. In a study of extra-thoracic SFTs, median overall survival duration ranged from 59 to 94 months and 5-year and 10-year survival rates were 89 and $73 \%$ respectively [49].

\section{Treatment}

Wide surgical excision is the mainstay of treatment and adjuvant radiotherapy and chemotherapy are not required in routine cases [98]. However, adjuvant radiotherapy has been suggested to improve the local control of tumor [99]. In meningeal tumors, SFTs (WHO grade 1) are treated with surgery alone while HPCs (WHO grades 2 \& 3) benefit from adjuvant radiotherapy [15]. Due to their rarity and lack of randomized control trials, there is no global consensus on treatment of SFTs. A multidisciplinary team approach is recommended for treatment and management of these tumors [19].

\section{Conclusions}

Accurate diagnosis is essential for appropriate treatment and management of SFTs. NAB2-STAT6 gene fusion and its IHC expression are consistently observed in these tumors. Immunohistochemistry is the most sensitive and specific means of diagnosing SFT and is practical and economical as well. Molecular studies require expensive equipment and well-trained staff which reduces their practicality and feasibility in resource limited laboratories of developing countries. Molecular testing may be helpful where IHC results are ambiguous. Thorough knowledge about the morphological variations of SFTs and correlation with clinical, IHC and molecular features are helpful in avoiding misdiagnosis.

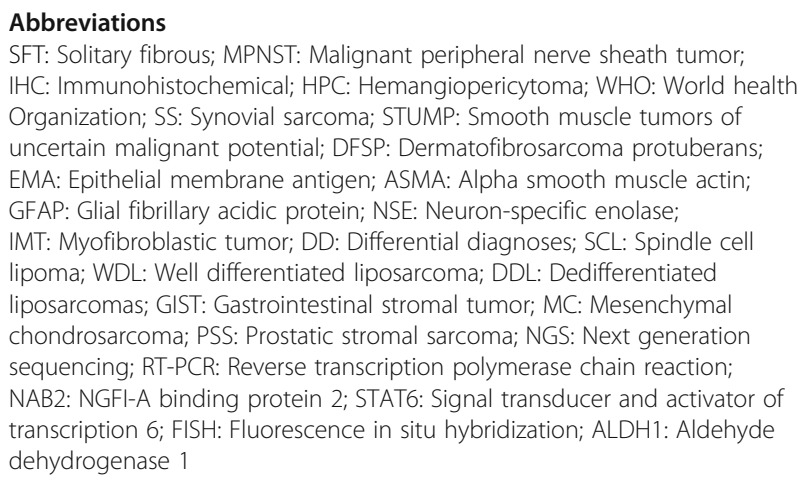

\section{Acknowledgements}

The authors thank Dr. Karen Fritchie of Mayo Clinic, USA for contributing the histology image of lipomatous SFT.

\section{Authors' contributions}

MUT and NUD did the literature review and drafted the manuscript. YKP prepared cases, extensively reviewed and revised the manuscript. JAG participated with the corresponding, reviewing, editing the drafted manuscript as per journal policy, and submission of the article. All authors participated in the design of the study. All authors read and approved the final manuscript.

Funding

No financial support was provided for this study.

\section{Availability of data and materials}

Data and materials of this work are available from the corresponding author on reasonable request.

\section{Declarations}

Ethics approval and consent to participate

Not applicable.

\section{Consent for publication}

Not applicable.

\section{Competing interests}

The authors declare that there are no conflicts of interest.

\section{Author details}

'Section of Histopathology, Department of Pathology and Laboratory Medicine, Aga Khan University Hospital, Karachi, Pakistan. ${ }^{2}$ Department of Pathology and Clinical Laboratory, French Medical Institute for Mothers and Children (FMIC), Kabul, Afghanistan. ${ }^{3}$ Emeritus Professor, Kyung Hee University, School of Medicine Vice President of Asia, International Academy of Pathology, U2Labs, Jangwon Medical Foundation 68 Geoma-ro,

Songpa-gu, Seoul 05755, South Korea.

Received: 12 January 2021 Accepted: 12 April 2021

Published online: 20 April 2021

\section{References}

1. Klemperer P, Rabin CB. Primary neoplasms of the pleura: a report of five cases. Arch Pathol. 1931;11:385-412.

2. Stout AP, Murray MR. Localized pleural mesothelioma. Arch Pathol. 1942;34: 951-64.

3. Stout AP, Himadi GM. Solitary (localized) mesothelioma of the pleura. Ann Surg. 1951;133(1):50-64. https://doi.org/10.1097/00000658-195101000-00005.

4. Stout AP, Murray MR. Hemangiopericytoma: a vascular tumor featuring Zimmermann's pericytes. Ann Surg. 1942;116(1):26-33. https://doi.org/10.1 097/00000658-194207000-00004.

5. Enzinger FM, Smith BH. Hemangiopericytoma: an analysis of 106 cases. Hum Pathol. 1976;7(1):61-82. https://doi.org/10.1016/S0046-8177(76)80006-8.

6. England DM, Hochholzer L, McCarthy MJ. Localized benign and malignant fibrous tumors of the pleura: a clinicopathologic review of 223 cases. Am J Surg Pathol. 1989;13(8):640-58. https://doi.org/10.1097/00000478-1 98908000-00003.

7. Goodlad JR, Fletcher CD. Solitary fibrous tumour arising at unusual sites: analysis of a series. Histopathology. 1991;19(6):515-22. https://doi.org/1 0.1111/j.1365-2559.1991.tb01499.x.

8. Gengler C, Guillou L. Solitary fibrous tumour and haemangiopericytoma: evolution of a concept. Histopathology. 2006;48(1):63-74. https://doi.org/1 0.1111/j.1365-2559.2005.02290.x.

9. Park MS, Araujo DM. New insights into the hemangiopericytoma/solitary fibrous tumor spectrum of tumors. Curr Opin Oncol. 2009;21(4):327-31. https://doi.org/10.1097/CCO.0b013e32832c9532.

10. Robinson DR, Wu YM, Kalyana-Sundaram S, Cao X, Lonigro RJ, Sung YS, et al. Identification of recurrent NAB2-STAT6 gene fusions in solitary fibrous tumor by integrative sequencing. Nat Genet. 2013;45(2):180-5. https://doi. org/10.1038/ng.2509.

11. Chmielecki J, Crago AM, Rosenberg M, O'Connor R, Walker SR, Ambrogio L, et al. Whole-exome sequencing identifies a recurrent NAB2-STAT6 fusion in solitary fibrous tumors. Nat Genet. 2013;45(2):131-2. https://doi.org/10.1038/ ng.2522.

12. Mohajeri A, Tayebwa J, Collin A, Nilsson J, Magnusson L, von Steyern FV, et al. Comprehensive genetic analysis identifies a pathognomonic NAB2/STAT6 fusion gene, nonrandom secondary genomic imbalances, and a characteristic 
gene expression profile in solitary fibrous tumor. Genes Chromosomes Cancer. 2013;52(10):873-86. https://doi.org/10.1002/gcc.22083.

13. Fletcher CDM, Bridge JA, Lee JC. Extrapleural solitary fibrous tumour. In: CDM F, Bridge JA, PCW H, Mertens F, editors. World Health Organisation Classification of Tumours of Soft Tissue and Bone. 4th ed. Lyon, France: IARC Press; 2013. p. 80-2.

14. Demicco EG, Fritchie K, Han A. Solitary fibrous tumour. In World Health Organisation Classification of Soft Tissue and Bone Tumours, $5^{\text {th }}$ ed.; WHO Classification of Tumours Editorial Board, Eds.; IARC Press, Lyon, France, 2019: pp. 104-108.

15. Giannini C, Rushing EJ, Hainfellner JA, Bouvier C, Figarella-Branger D, von Deimling A, Wesseiing P, Antonescu CR. Solitary fibrous tumour/ Haemangiopericytoma. In WHO Classification of Tumours of the Central Nervous System, Revised 4th ed.; Louis DN, Ohgaki H, Wiestler OD, Cavenee WK. Ellison DW, Figarella-Branger D, Perry A, Reifenberger G, von Deimling A, Eds.; IARC Press, Lyon, France, 2016; pp. 249-254.

16. Thway K, Jordan S, Fisher C, Nicholson AG. Updates in the approach to intrathoracic sarcomas. Histopathology. 2015;67(6):755-70. https://doi.org/1 $0.1111 /$ his. 12771 .

17. Ronchi A, Cozzolino I, Marino FZ, et al. Extrapleural solitary fibrous tumor: a distinct entity from pleural solitary fibrous tumor. An update on clinical, molecular and diagnostic features. Ann Diagn Pathol. 2018;34:142-50. https://doi.org/10.1016/j.anndiagpath.2018.01.004.

18. Kim JM, Choi YL, Kim YJ, Park HK. Comparison and evaluation of risk factors for meningeal, pleural, and extrapleural solitary fibrous tumors: a clinicopathological study of 92 cases confirmed by STAT6 immunohistochemical staining. Pathol Res Pract. 2017;213(6):619-25. https:// doi.org/10.1016/j.prp.2017.04.026

19. Davanzo B, Emerson RE, Lisy M, Koniaris LG, Kays JK. Solitary fibrous tumor. Transl Gastroenterol Hepatol. 2018;3:94. https://doi.org/10.21037/tgh.2018.11.02.

20. Bartheleme S, Geddert H, Boltze C, et al. Solitary fibrous tumors/ hemangiopericytomas with different variants of the NAB2-STAT6 gene fusion are characterized by specific histomorphology and distinct clinicopathological features. Am J Pathol 2014; 184:1209-1218, 4, DOl: https://doi.org/10.1016/j.ajpath.2013.12.016.

21. Goldblum JR, Folpe AL, Weiss SW. Enzinger and Weiss's Soft Tissue Tumors. 7th ed. Philadelphia: Elsevier; Philadelphia, USA; 2019. p. 1133-47.

22. Feasel P, Al-lbraheemi A, Fritchie $K$, et al. Superficial solitary fibrous tumor: a series of 26 cases. Am J Surg Pathol. 2018;42(6):778-85. https://doi.org/10.1 097/PAS.0000000000001027.

23. Zafar H, Takimoto CH, Weiss G. Doege-potter syndrome: hypoglycemia associated with malignant solitary fibrous tumor. Med Oncol. 2003;20(4): 403-8. https://doi.org/10.1385/MO:20:4:403.

24. Steigen SE, Schaeffer DF, West RB, Nielsen TO. Expression of insulin-like growth factor 2 in mesenchymal neoplasms. Mod Pathol. 2009;22(7):914-21. https://doi.org/10.1038/modpathol.2009.48.

25. Machado I, Nieto-Morales G, Cruz J, Navarro S, Giner F, Ferrandez A, et al. Controversial issues in soft tissue solitary fibrous tumors: a pathological and molecular review. Pathol Int. 2020;70(3):129-39. https://doi.org/10.1111/ pin.12894.

26. Lee JY, Park SE, Shin SJ, Kim CW, Kim SS, Kim KH. Solitary fibrous tumor with myxoid stromal change. Am J Dermatopathol. 2015;37(7):570-3. https://doi. org/10.1097/DAD.0000000000000154.

27. de Saint Aubain Somerhausen N, Rubin BP, CDM F. Myxoid solitary fibrous tumor: a study of seven cases with emphasis on differential diagnosis. Mod Pathol. 1999;12(5):463-71.

28. Tsuneyoshi M, Daimaru Y, Enjoji M. Malignant hemangiopericytoma and other sarcomas with hemangiopericytoma-like pattern. Pathol Res Pract. 1984;178(5):446-53. https://doi.org/10.1016/50344-0338(84)80004-7.

29. Nappi O, Ritter JH, Pettinato G, Wick MR. Hemangiopericytoma: histopathological pattern or clinicopathologic entity? Semin Diagn Pathol. 1995:12(3):221-32.

30. Fletcher CDM. Haemangiopericytoma e a dying breed? Reappraisal of an entity and its variants: a hypothesis. Curr Diagn Pathol 1994; 1:19-23, 1, DOl: https://doi.org/10.1016/50968-6053(06)80005-0.

31. Guillou L, Gebhard S, Coindre JM. Lipomatous hemangiopericytoma: a fatcontaining variant of solitary fibrous tumor? Clinicopathologic, immunohistochemical, and ultrastructural analysis of a series in favor of a unifying concept. Hum Pathol. 2000;31(9):1108-15. https://doi.org/10.1053/ hupa.2000.9777.
32. Jing HB, Meng QD, Tai YH. Lipomatous hemangiopericytoma of the stomach: a case report and a review of literature. World J Gastroenterol. 2011;17(43):4835-8. https://doi.org/10.3748/wjg.v17.i43.4835.

33. Barazani $Y$, Tareen B. Rare case of paratesticular solitary fibrous tumour (lipomatous hemangiopericytoma). Can Urol Assoc J. 2012;6(3):E131-3. https://doi.org/10.5489/cuaj.11092.

34. Davies PE, Davis GJ, Dodd T, Selva D. Orbital lipomatous haemangiopericytoma: an unusual variant. Clin Exp Ophthalmol. 2002;30(4): 281-3. https://doi.org/10.1046/j.1442-9071.2002.00542.x.

35. Dei Tos AP, Seregard S, Calonje E, Chan JK, Fletcher CD. Giant cell angiofibroma a distinctive orbital tumor in adults. Am J Surg Pathol. 1995; 19(11):1286-93.

36. Guillou L, Gebhard S, Coindre JM. Orbital and extraorbital giant cell angiofibrma: a giant cell-rich variant of solitary fibrous tumor? Clinicopathologic and immunohistochemical analysis of a series in favor of a unifying concept. Am J Surg Pathol. 2000;24(7):971-9. https://doi.org/10.1 097/00000478-200007000-00008.

37. Sigel JE, Fisher C, Vogt D, Goldblum JR. Giant cell angiofibroma of the inguinal region. Ann Diagn Pathol. 2000;4(4):240-4. https://doi.org/10.1053/a dpa.2000.8129.

38. Mosquera JM, Fletcher $\mathrm{CD}$. Expanding the spectrum of malignant progression in solitary fibrous tumors: a study of 8 cases with a discrete anaplastic component-is this dedifferentiated SFT? Am J Surg Pathol. 2009;33(9):1314-21. https://doi.org/10.1097/PAS.0b013e3181a6cd33.

39. Thway K, Hayes A, leremia E, Fisher C. Heterologous osteosarcomatous and rhabdomyosarcomatous elements in dedifferentiated solitary fibrous tumor: further support for the concept of dedifferentiation in solitary fibrous tumor Ann Diagn Pathol. 2013;17(5):457-63. https://doi.org/10.1016/j.anndiagpath.2 012.08.006.

40. Lu C, Alex D, Benayed R, Rosenblum M, Hameed M. Solitary fibrous tumor with neuroendocrine and squamous dedifferentiation: a potential diagnostic pitfall. Hum Pathol. 2018;77:175-80. https://doi.org/10.1016/j. humpath.2017.12.024.

41. Collini P, Negri T, Barisella M, Palassini E, Tarantino E, Pastorino U, et al. High-grade sarcomatous overgrowth in solitary fibrous tumors: a clinicopathologic study of 10 cases. Am J Surg Pathol. 2012;36(8):1202-15. https://doi.org/10.1097/PAS.0b013e31825748fo.

42. Subramaniam MM, Lim XY, Venkateswaran K, Shuen CS, Soong R, Petersson F. Dedifferentiated solitary fibrous tumour of the nasal cavity: the first case reported with molecular characterization of a TP53 mutation. Histopathology. 2011;59(6):1269-74. https://doi.org/10.1111/j.1365-2559.2 011.03997.x.

43. Yamada Y, Kohashi K, Kinoshita I, Yamamoto H, Iwasaki T, Yoshimoto M, et al. Clinicopathological review of solitary fibrous tumors: dedifferentiation is a major cause of patient death. Virchows Arch. 2019:475(4):467-77. https://doi.org/10.1007/s00428-019-02622-9.

44. Moran CA, Suster S, Koss MN. The spectrum of histologic growth patterns in benign and malignant fibrous tumors of the pleura. Semin Diagn Pathol. 1992:9(2):169-80.

45. Schirosi L, Lantuejoul S, Cavazza A, Murer B, Yves Brichon P, Migaldi M, Sartori G, Sgambato A, Rossi G Pleuro-pulmonary solitary fibrous tumors: a clinicopathologic, immunohistochemical, and molecular study of 88 cases confirming the prognostic value of de Perrot staging system and p53 expression, and evaluating the role of ckit, BRAF, PDGFRs (alpha/beta), cmet, and EGFR. Am J Surg Pathol 2008; 32:1627-1642, 11, DOl: https://doi. org/10.1097/PAS.0b013e31817a8a89.

46. Cranshaw IM, Gikas PD, Fisher C, Thway K, Thomas JM, Hayes AJ. Clinical outcomes of extra-thoracic solitary fibrous tumours. Eur J Surg Oncol. 2009; 35(9):994-8. https://doi.org/10.1016/j.ejso.2009.02.015.

47. Rao N, Colby TV, Falconieri G, Cohen H, Moran CA, Suster S. Intrapulmonary solitary fibrous tumors: clinicopathologic and immunohistochemical study of 24 cases. Am J Surg Pathol. 2013;37(2):155-66. https://doi.org/10.1097/PA S.0b013e31826a92f5.

48. Pasquali S, Gronchi A, Strauss D, Bonvalot S, Jeys L, Stacchiotti S, et al. Resectable extra-pleural and extra-meningeal solitary fibrous tumours: a multi-Centre prognostic study. Eur J Surg Oncol. 2016;42(7):1064-70. https:// doi.org/10.1016/j.ejso.2016.01.023

49. Demicco EG, Park MS, Araujo DM, Fox PS, Bassett RL, Pollock RE, et al. Solitary fibrous tumor: a clinicopathological study of 110 cases and proposed risk assessment model. Mod Pathol. 2012;25(9):1298-306. https:// doi.org/10.1038/modpathol.2012.83 
50. Park HK, Yu DB, Sung M, Oh E, Kim M, Song JY, et al. Molecular changes in solitary fibrous tumor progression. J Mol Med. 2019;97(10):1413-25. https:// doi.org/10.1007/s00109-019-01815-8.

51. Bianchi G, Sambri A, Pedrini E, Pazzaglia L, Sangiorgi L, Ruengwanichayakun $P$, et al. Histological and molecular features of solitary fibrous tumor of the extremities: clinical correlation. Virchows Arch. 2020;476(3):445-54. https:// doi.org/10.1007/s00428-019-02650-5.

52. Demicco EG, Wagner MJ, Maki RG, Gupta V, lofin I, Lazar AJ, et al. Risk assessment in solitary fibrous tumors: validation and refinement of a risk stratification model. Mod Pathol. 2017;30(10):1433-42. https://doi.org/10.103 8/modpathol.2017.54.

53. Miettinen M. Immunohistochemistry of soft tissue tumours - review with emphasis on 10 markers. Histopathology. 2014;64(1):101-18. https://doi. org/10.1111/his.12298.

54. Vivero M, Doyle LA, Fletcher CD, Mertens F, Hornick JL. GRIA2 is a nove diagnostic marker for solitary fibrous tumour identified through gene expression profiling. Histopathology. 2014;65(1):71-80. https://doi.org/ $0.1111 /$ his. 12377 .

55. Doyle LA, Vivero M, Fletcher CD, Mertens F, Hornick JL. Nuclear expression of STAT6 distinguishes solitary fibrous tumor from histologic mimics. Mod Pathol. 2014;27(3):390-5. https://doi.org/10.1038/modpathol.2013.164.

56. Schweizer L, Koelsche C, Sahm F, Piro RM, Capper D, Reuss DE, et al. Meningeal hemangiopericytoma and solitary fibrous tumors carry the NAB2-STAT6 fusion and can be diagnosed by nuclear expression of STAT6 protein. Acta Neuropathol. 2013;125(5):651-8. https://doi.org/10.1007/s004 01-013-1117-6.

57. Bouvier C, Bertucci F, Métellus $P$, Finetti $P$, de Paula AM, Forest $F$, et al. ALDH1 is an immunohistochemical diagnostic marker for solitary fibrous tumours and haemangiopericytomas of the meninges emerging from gene profiling study. Acta Neuropathol Commun. 2013;1(1):10. https://doi.org/1 0.1186/2051-5960-1-10

58. Han $Y$, Zhang Q, Yu X, Han X, Wang H, Xu Y, et al. Immunohistochemical detection of STAT6, CD34, CD99 and BCL-2 for diagnosing solitary fibrous tumors/hemangiopericytomas. Int J Clin Exp Pathol. 2015;8(10):13166-75.

59. Suster S, Fisher C, Moran CA. Expression of bcl-2 oncoprotein in benign and malignant spindle cell tumors of soft tissue, skin, serosal surfaces, and gastrointestinal tract. Am J Surg Pathol. 1998;22(7):863-72. https://doi.org/1 0.1097/00000478-199807000-00008

60. Yoshida A, Tsuta K, Ohno M, Yoshida M, Narita Y, Kawai A, et al. STAT6 immunohistochemistry is helpful in the diagnosis of solitary fibrous tumors. Am J Surg Pathol. 2014;38(4):552-9. https://doi.org/10.1097/PAS. 0000000000000137.

61. Doyle LA, Tao D, Mariño-Enríquez A. STAT6 is amplified in a subset of dedifferentiated liposarcoma. Mod Pathol. 2014;27(9):1231-137. https://doi. org/10.1038/modpathol.2013.247.

62. Demicco EG, Harms PW, Patel RM, Smith SC, Ingram D, Torres K, et al. Extensive survey of STAT6 expression in a large series of mesenchymal tumors. Am J Clin Pathol. 2015;143(5):672-82. https://doi.org/10.1309/A JCPN25NJTOUNPNF.

63. Ouladan S, Trautmann M, Orouji E, et al. Differential diagnosis of solitary fibrous tumors: a study of 454 soft tissue tumors indicating the diagnostic value of nuclear STAT6 relocation and ALDH1 expression combined with in situ proximity ligation assay. Int J Oncol. 2015;46(6):2595-605. https://doi. org/10.3892/ijo.2015.2975.

64. Guner G, Bishop JA, Bezerra SM, Taheri D, Zahavi DJ, Mendoza Rodriguez MA, et al. The utility of STAT6 and ALDH1 expression in the differential diagnosis of solitary fibrous tumor versus prostate-specific stromal neoplasms. Hum Pathol. 2016;54:184-8. https://doi.org/10.1016/j.humpath.2 016.03.011.

65. Lecoutere E, Creytens D. Multifocal cytokeratin expression in pleural and abdominal malignant solitary fibrous tumors: an unusual diagnostic pitfall. Virchows Arch. 2015;467(1):119-21. https://doi.org/10.1007/s00428-015-1768-x.

66. Thway K, Ng W, Noujaim J, Jones RL, Fisher C. The current status of solitary fibrous tumor: diagnostic features, variants, and genetics. Int I Surg Pathol. 2016;24(4):281-92. https://doi.org/10.1177/1066896915627485.

67. Song MJ, Cho KJ, Lee JS, Song JS. Application of MDM2 fluorescence in situ hybridization and immunohistochemistry in distinguishing dedifferentiated liposarcoma from other high-grade sarcomas. Appl Immunohistochem Mol Morphol. 2017;25(10):712-9. https://doi.org/10.1097/PAl.0000000000000365.

68. Sugita S, Aoyama T, Kondo K, Keira Y, Ogino J, Nakanishi K, et al. Diagnostic utility of NCOA2 fluorescence in situ hybridization and Stat6 immunohistochemistry staining for soft tissue angiofibroma and morphologically similar fibrovascular tumors. Hum Pathol. 2014;45(8):158896. https://doi.org/10.1016/j.humpath.2013.12.022.

69. Takeda M, Kojima K, Taniguchi Y, Yoon HE, Matsumura A, Ohbayashi C, et al. Fat-forming variant of solitary fibrous tumor of the pleura, mimicking spindle cell lipoma. Pathol Int. 2019;69(5):309-11. https://doi.org/10.1111/ pin.12787.

70. Ma Y, Siegal GP, Wei S. Solitary, adult-onset, intraosseous myofibroma of the finger: report of a case and review of literature. Hand (NY). 2015;10(3):550-4. https://doi.org/10.1007/s11552-014-9729-4.

71. Fritchie KJ, Carver P, Sun Y, Batiouchko G, Billings SD, Rubin BP, et al. Solitary fibrous tumor: is there a molecular relationship with cellular Angiofibroma, spindle cell Lipoma, and mammary-type Myofibroblastoma? Am J Clin Pathol. 2012;137(6):963-70. https://doi.org/10.1309/AJCPQEG6YNN6CNAL.

72. Lee JC, Fletcher CDM. Malignant fat-forming solitary fibrous tumor (so-called "lipomatous hemangiopericytoma"): Clinicopathologic analysis of 14 cases. Am J Surg Pathol. 2011;35(8):1177-85. https://doi.org/10.1097/PAS.0b013e31 8219cd0b.

73. Folpe AL, Devaney K, Weiss SW. Lipomatous hemangiopericytoma: a rare variant of hemangiopericytoma that may be confused with liposarcoma. Am J Surg Pathol. 1999;23(10):1201-7. https://doi.org/10.1097/00000478-1 99910000-00004.

74. Carter JM, Weiss SW, Linos K, DiCaudo DJ, Folpe AL. Superficial CD34positive fibroblastic tumor: report of 18 cases of a distinctive low-grade mesenchymal neoplasm of intermediate (borderline) malignancy. Mod Pathol. 2014;7:294-302.

75. Sheng WQ, Hashimoto H, Okamoto S, Ishida T, Meis-Kindblom JM, Kindblom LG, et al. Expression of COL1A1-PDGFB fusion transcripts in superficial adult fibrosarcoma suggests a close relationship to dermatofibrosarcoma protuberans. J Pathol. 2001;194(1):88-94. https://doi.org/10.1002/path.839.

76. Barresi V, Caffo M, Tuccari G. Classification of human meningiomas: lights, shadows, and future perspectives. J Neurosci Res. 2016;94(12):1604-12. https://doi.org/10.1002/jnr.23801.

77. Ahmad Z, Tariq MU, Din NU. Meningeal solitary fibrous tumor/ hemangiopericytoma: emphasizing on STAT 6 immunohistochemistry with a review of literature. Neurol India. 2018;66(5):1419-26. https://doi.org/10.41 03/0028-3886.241365.

78. Rudzinski ER. Embryonal Rhabdomyosarcoma. In: WHO Classification of Tumours Editorial Board, editor. World Health Organisation Classification of Soft Tissue and Bone Tumours. 5th ed. Lyon, France: IARC Press; 2019. p. 201-4.

79. Cessna MH, Zhou H, Perkins SL, Tripp SR, Layfield L, Daines C, et al. Are myogenin and myoD1 expression specific for rhabdomyosarcoma? A study of 150 cases, with emphasis on spindle cell mimics. Am J Surg Pathol. 2001; 25(9):1150-7. https://doi.org/10.1097/00000478-200109000-00005.

80. Saeed O, Zhang S, Cheng L, Lin J, Alruwaii F, Chen S. STAT6 expression in solitary fibrous tumor and histologic mimics: a single institution experience. Appl Immunohistochem Mol Morphol. 2020;28(4):311-5. https://doi.org/10.1 097/PAl.0000000000000745.

81. Stanisce L, Ahmad N, Levin K, Deckard N, Enriquez M, Brody J, et al. Solitary fibrous tumors in the head and neck: comprehensive review and analysis. Head Neck Pathol. 2020;14(2):516-24. https://doi.org/10.1007/s12105-019-01 058-6.

82. Naso JR, Chiu CG, Goecke ME, Chang D, Shiau CJ. Benign spindle cell lesions of the breast: a diagnostic approach to solitary fibrous tumour, nodular pseudoangiomatous stromal hyperplasia and nodular fasciitis. J Clin Pathol. 2019;72(6):438-42. https://doi.org/10.1136/jclinpath-2018-205561.

83. Hansel DE, Netto GJ, Montgomery EA, Epstein Jl. Mesenchymal tumors of the prostate. Surg Pathol Clin. 2008;1(1):105-28. https://doi.org/10.1016/j.pa th.2008.07.003.

84. Hebenstreit D, Wirnsberger G, Horejs-Hoeck J, Duschl A. Signaling mechanisms, interaction partners, and target genes of STAT6. Cytokine Growth Factor Rev. 2006;17(3):173-88. https://doi.org/10.1016/j.cytogfr.2006. 01.004.

85. Bhattacharyya S, Fang F, Tourtellotte W, Varga J. Egr-1: new conductor for the tissue repair orchestra directs harmony (regeneration) or cacophony (fibrosis). J Pathol. 2013;229(2):286-97. https://doi.org/10.1002/path.4131.

86. Svaren J, Sevetson BR, Apel ED, Zimonjic DB, Popescu NC, Milbrandt J. NAB2, a corepressor of NGFI-A (Egr-1) and Krox20, is induced by proliferative and differentiative stimuli. Mol Cell Biol. 1996;16(7):3545-53. https://doi.org/10.1128/MCB.16.7.3545. 
87. Ingram JL, Antao-Menezes A, Mangum JB, Lyght O, Lee PJ, Elias JA, et al. Opposing actions of Stat1 and Stat6 on IL-13-induced upregulation of early growth response-1 and platelet-derived growth factor ligands in pulmonary fibroblasts. J Immunol. 2006;177(6):4141-8. https://doi.org/10.4049/ jimmunol.177.6.4141.

88. Hajdu M, Singer S, Maki RG, Schwartz GK, Keohan ML, Antonescu CR. IGF2 overexpression in solitary fibrous tumours is independent of anatomical location and is related to loss of imprinting. J Pathol. 2010;221(3):300-7. https://doi.org/10.1002/path.2715.

89. Yamada Y, Kohashi K, Fushimi F, Takahashi Y, Setsu N, Endo M, et al. Activation of the Akt-mTOR pathway and receptor tyrosine kinase in patients with solitary fibrous tumors. Cancer. 2014;120(6):864-76. https://doi. org/10.1002/cncr.28506.

90. Demicco EG, Wani K, Fox PS, Bassett RL, Young ED, Lev D, et al. Histologic variability in solitary fibrous tumors reflects angiogenic and growth factor signaling pathway alterations. Hum Pathol. 2015;46(7):1015-26. https://doi. org/10.1016/j.humpath.2015.03.014

91. Tallini G, Dorfman H, Brys P, Dal Cin P, de Wever I, Fletcher CDM, et al. Correlation between clinicopathological features and karyotype in 100 cartilaginous and chordoid tumours. A report from the chromosomes and morphology (CHAMP) collaborative study group. J Pathol. 2002;196(2):194203. https://doi.org/10.1002/path.1023.

92. Dal Cin P, Sciot R, Fletcher CD, et al. Trisomy 21 in solitary fibrous tumor. Cancer Genet Cytogenet. 1996;86(1):58-60. https://doi.org/10.1016/0165-4 608(95)00179-4.

93. Havlik DM, Farnath DA, Bocklage T. Solitary fibrous tumor of the orbit with t(9;22)(q31;p13). Arch Pathol Lab Med. 2000;124(5):756-8. https://doi.org/10. 5858/2000-124-0756-SFTOTO.

94. Horton ES, Dobin SM, Donner LR. A clonal $t(8 ; 12)(p 11.2 ; q 24.3)$ as the sole abnormality in a solitary fibrous tumor of the pleura. Cancer Genet Cytogenet. 2007;172(1):77-9. https://doi.org/10.1016/j.cancergencyto.2006. 07.015.

95. Morimitsu Y, Nakajima M, Hisaoka M, Hashimoto H. Extrapleural solitary fibrous tumor: clinicopathologic study of 17 cases and molecular analysis of the p53 pathway. APMIS. 2000;108(9):617-25. https://doi.org/10.1034/j.16000463.2000.d01-105.x.

96. Van Houdt WJ, Westerveld CM, Vrijenhoek JE, et al. Prognosis of solitary fibrous tumors: a multicenter study. Ann Surg Oncol. 2013;20(13):4090-5 https://doi.org/10.1245/s10434-013-3242-9.

97. Gold JS, Antonescu CR, Hajdu C, Ferrone CR, Hussain M, Lewis JJ, et al. Clinicopathologic correlates of solitary fibrous tumors. Cancer. 2002;94(4): 1057-68. https://doi.org/10.1002/cncr.10328.

98. Cardillo G, Carbone L, Carleo F, Masala N, Graziano P, Bray A, et al. Solitary fibrous tumors of the pleura: an analysis of 110 patients treated in a single institution. Ann Thorac Surg. 2009;88(5):1632-7. https://doi.org/10.1016/j.a thoracsur.2009.07.026.

99. Bishop AJ, Zagars GK, Demicco EG, Wang WL, Feig BW, Guadagnolo BA. Soft tissue solitary fibrous tumor: combined surgery and radiation therapy results in excellent local control. Am J Clin Oncol. 2018;41(1):81-5. https://doi.org/1 $0.1097 /$ COC.0000000000000218

\section{Publisher's Note}

Springer Nature remains neutral with regard to jurisdictional claims in published maps and institutional affiliations.

Ready to submit your research? Choose BMC and benefit from:

- fast, convenient online submission

- thorough peer review by experienced researchers in your field

- rapid publication on acceptance

- support for research data, including large and complex data types

- gold Open Access which fosters wider collaboration and increased citations

- maximum visibility for your research: over $100 \mathrm{M}$ website views per year

At $\mathrm{BMC}$, research is always in progress.

Learn more biomedcentral.com/submissions 